\title{
Haemoparasites and Polyparasitism of Intestinal Helminths of Cattle Slaughtered in Abeokuta, Nigeria and Their Implications for One Health.
}

Oluwadamilare Dauda ( $\sim$ daredauda92@gmail.com )

Osun State University https://orcid.org/0000-0003-3846-4401

Olabanji Surakat

Osun State University

Muhammed Rufai

Osun State University

Foluke Akande

Federal University of Agriculture Abeokuta

Monsuru Adeleke

Osun State University

Sunday Akinde

Osun State University

\section{Research Article}

Keywords: Prevalence, Haemoparasites, Intestinal helminths, Cattle, Abeokuta, One Health

Posted Date: January 25th, 2022

DOl: https://doi.org/10.21203/rs.3.rs-1266678/v3

License: (9) (i) This work is licensed under a Creative Commons Attribution 4.0 International License. Read Full License

Version of Record: A version of this preprint was published at Pan African Journal of Life Sciences on April 1st, 2022. See the published version at https://doi.org/10.36108/pajols/2202/60.0150. 


\section{TITLE PAGE}

2 TYPE OF MANUSCRIPT: RESEARCH

3 TITLE: HAEMOPARASITES AND POLYPARASITISM OF INTESTINAL HELMINTHS OF

4 CATTLE SLAUGHTERED IN ABEOKUTA, NIGERIA AND THEIR IMPLICATIONS FOR

5 ONE HEALTH.

6 AUTHORS AND AFFILIATIONS

7 1. Author 1 - Oluwadamilare Ganiu Dauda

8 Affiliation: Osun State University, Osogbo, Osun State, Nigeria.

9 2. Author 2 - Olabanji Surakat

10 Affiliation: Osun State University, Osogbo, Osun State, Nigeria.

11 3. Author 3 - Mohammed Rufai

12 Affiliation: Osun State University, Osogbo, Osun State, Nigeria.

13 4. Author 4 - Foluke Akande

14 Affiliation: Federal University of Agriculture, Abeokuta, Ogun State, Nigeria

15 5. Author 5 - Sunday Akinde

16 Affiliation: Osun State University, Osogbo, Osun State, Nigeria.

17 6. Author 6 - Monsuru Adeleke

18 Affiliation: Osun State University, Osogbo, Osun State, Nigeria.

$19 @$ @orresponding author

20 E-mail: dare_dauda@yahoo.com

21 
23 Background: Haemoparasites and intestinal helminths are major constraints to livestock 24 production resulting in huge economic loss and some helminth parasites of cattle are of serious 25 public health concern. This study investigated the prevalence of haemoparasites and 26 polyparasitism of intestinal helminths amongst cattle slaughtered in two major abattoirs of 27 Abeokuta metropolis and their implications for One Health.

28 Results: Results showed prevalence for Trypanosoma spp., Babesia spp., Anaplasma spp. and 29 Theileria spp. to be $8.3 \%, 27.34 \%, 20.7 \%$ and $0.39 \%$ respectively. For intestinal parasites, 30 prevalence for Strongyle eggs was found to be $73.82 \%$, Neoascaris vitulorum $0.8 \%$, Fasciola spp. 31 10.15\%, Moniezia spp. 4.3\%, Eimeria oocyst 35.94\% and Cryptosporidium oocyst was $1.17 \%$. 32 Total prevalence for coinfection of haemoparasite and intestinal helminths was 42.6\%. Breed33 specific prevalence for co-infection of haemoparasites and intestinal parasites showed 55.96\%, $34 \quad 37.6 \%$ and $6.4 \%$ for White Fulani, Red Bororo and Sokoto Gudali respectively, which was 35 statistically insignificant $(P>0.05)$. With respect to sex, females had higher prevalence $92(84.4 \%)$ 36 of coinfection of haemoparasites and intestinal helminths than males 17 (15.6\%), which was 37 statistically significant $(P<0.05)$.

38 Conclusions: This study revealed a high prevalence of haemoparasites and intestinal parasites in 39 cattle slaughtered in Abeokuta, Nigeria. This study therefore recommends strict compliance of 40 meat inspection at abattoirs and the need for immediate operationalization and implementation of 41 a sustainable Preventive One Health intervention in order to mitigate against outbreak of zoonoses 42 in Abeokuta. 
67 Several studies have been conducted on haemoparasites in Nigeria. Imalele et al. (2019), in their

\section{BACKGROUND}

In Nigeria, ruminants such as the sheep, goats and cattle constitute the livestock largely reared by farmers in the agricultural sector of the country with sheep having a population of 38.5million, 57.4million goats and 19.2 million cattle (Adebowale et al. 2020) with larger population of these animals largely concentrated in the northern region of the country than the south (LawalAdebowale, 2012). Among the ruminants, cattle are regarded as the main source of animal protein in most household and their products such as milk, hoof, bones, blood, hides and skin have great economic benefits (Sam-wobo et al. 2016). 90\% of the cattle population in Nigeria are raised under the pastoral husbandry system of Fulani herders (Musa et al. 2014). Under the pastoral husbandry system where cattle are extensively grazed on pastures and forests, cattle may be exposed to various arthropod vectors of haemoparasites (Kamani et al. 2010). Livestock rearing is faced with a number of constraints which limits productivity and profitability (Bakre et al. 2020). A leading constraint to livestock production is animal diseases which constitute a major obstacle to economic development and of importance is parasitism, a leading cause of production losses due to mortality, reduction in weight gain, low fertility in most countries of the world (Musa et al. 2014).

Haemoparasites are found in the blood stream and tissues of vertebrates throughout the world (Pam et al. 2013). Haemoprotozoan diseases especially Babesiosis, Anaplasmosis, Trypanosomiasis and Theileriosis are major diseases causing major constraints to the health and productivity of cattle (Ochai \& Kolhatkar, 2007). Even though there is a global distribution of haemoparasites, the distribution of these infections changes continuously due to the migration and transportation of vectors and animals and an increased globalization of both live animals and their products (Stuen, study on the prevalence of haemoparasites in cattle slaughtered for sale in Calabar reported a prevalence of 11.66\%. Akande et al. (2010) in their study on the prevalence of haemoparasites in Abeokuta reported overall infection of 51\%. In another study by Okwelum et al. (2021) in Abeokuta, a prevalence of haemoparasites in slaughtered cattle was reported to be $22 \%$.

Helminthic infection, according to Faye et al. (2003), is a cosmopolitan disease that affects ruminants, most particularly in places with poor hygiene and feeding. The gastrointestinal parasites, mainly helminths are responsible for the clinical and subclinical manifestation of 
75 diseases of livestock and this has been a major impedance to livestock production in Nigeria (Biu 76 \& Adindu, 2004). Gastrointestinal parasites of cattle have caused production loss to livestock by 77 retarding the growth, lowering productivity and increasing susceptibility of animals to other 78 infections (Yadav et al. 2006). Lowered fertility, reduced work capacity, involuntary culling and 79 treatment cost are other indirect economic losses due to gastrointestinal parasites (Zahid et al.. 80 81 82 83

84 Weakness of the body, abdominal pains, anorexia, diarrhea, enteritis, constipation, loss of weight, 85 jaundice, rough hair coat, anaemia, alopecia, coughing, labour breathing, fever, haemoglobinuria, 86 infertility, abortion and sudden death are clinical manifestations of haemoparasites and 87 gastrointestinal parasites of cattle noted by Otto et al. (2000), Love \& Hutchinson (2003) and Otto 88 (2005).

In Ogun state, seperate studies on haemoparasites and intestinal helminths have been previously conducted, however, there is a need to continually have updated information on the prevalence of haemoparasites and intestinal helminths especially in cattle slaughtered in Abeokuta metropolis. Also, this study became imperative considering the emphasis on food safety by the Food and Agriculture Organization (FAO). The data from this study will therefore provide substantial and updated information on the prevalence of haemoparasites and intestinal helminths in cattle slaughtered in Abeokuta, their implications for public health and also provide epidemiological data for effective surveillance and control of zoonotic diseases in Abeokuta metropolis. 


\section{METHOD}

\subsection{The Study Area}

105 The study was conducted in two major abattoirs in Abeokuta metropolis, the Ogun state capital. 106 The Lafenwa abattoir $\left(7^{\circ} 09^{\prime} 46^{\prime \prime} \mathrm{N}\right.$ and $\left.3^{\circ} 19^{\prime} 40^{\prime \prime} \mathrm{E}\right)$ located in Abeokuta North local government 107 area of Ogun state, Nigeria. Aladesanmi (Asejere) abbatoir, is in Abeokuta South Local 108 Government $\left(7^{\circ} 09^{\prime} 45^{\prime \prime} \mathrm{N}\right.$ and $\left.3^{\circ} 22^{\prime} 33^{\prime \prime} \mathrm{E}\right)$. These two abattoirs are the major abattoir in Abeokuta 109 metropolis with the Lafenwa abattoir slaughtering an average of 100 cattle a day.

\subsection{Study Design and Selection of Cattle}

The survey of haemoparasites and polyparasitism of intestinal parasites in cattle slaughtered in the two abattoirs was carried out between February 2021 and June 2021. A total of 256 cattle were selected and tagged from the lots prepared for daily slaughter. The samples cut across both sexes and different breeds of cattle that include White Fulani, Sokoto Gudali, Red Fulani, Crossbreed and N'Dama. The cattle were grouped into $<2$ years and $>2$ years using their dentition.

\subsection{Ethics Approval}

117 Approval and permission for the study was given by the ethics committee of Veterinary Services 118 Unit of the Ogun State Ministry of Agriculture, Abeokuta, Ogun State.

\subsection{Blood Sample Collection}

$1205 \mathrm{ml}$ of blood samples were collected from the jugular vein of the animal at the point of slaughtering 121 in a sterile ethylene diamine tetra acetic acid (EDTA) tube which was labelled immediately with 122 the location, breed, sex and age of the cattle and placed in ice pack. The samples were then 123 transported to the laboratory of the Department of Veterinary Microbiology and Parasitology, 124 Federal University of Agriculture, Abeokuta for laboratory analysis.

\section{$125 \quad 2.5$ Faecal Sample Collection}

$126100 \mathrm{~g}$ of faecal samples were obtained directly from the rectum of each animal with the use of a 127 hand glove. The samples were immediately labelled with the location, breed, sex and age of cattle 128 before been transferred into a clean disposable polythene bag and transported in ice pack to the 
laboratory of the Department of Veterinary Microbiology and Parasitology, Federal University of Agriculture, Abeokuta for laboratory analysis.

\subsection{Blood Sample Analysis}

The Packed Cell Volume (PCV) of the blood samples was done to check for anaemia using the technique of Schalm et al. (1975). The haemoparasites were detected using three techniques. The techniques are wet mount, stained thin blood smear and the buffy coat as prescribed by Cheesbrough (1998). The wet mount specimens and buffy coat were examined using the X10 and X40 objective lens while the thin blood smears were examined using the X100 objective lens.

\subsubsection{Packed Cell Volume}

The EDTA tube containing blood sample was held at an angle to mix the blood sample and the index finger placed on top of the capillary tube in order to track blood into the capillary tube until it was about $3 / 4$ full. The outside of the capillary tube was wiped with clean tissue and the capillary tube was placed on the plasticine (sealant) and gently pressed into the plasticine. The capillary tubes were placed in the Hawksley haematocrit centrifuge with the plasticine end of the capillary tubes placed against the rubber (outer) edge to stop the blood from spilling out when spun. It was centrifuged at $12000 \mathrm{rpm}$ for $5 \mathrm{mins}$. Once the centrifuge came to a complete stop, the lid was opened and the tubes checked to ensure there were no leakages. Each of the capillary tubes was then removed and placed on the haematocrit reader. The tube was adjusted on the slider so that the top of the plasticine was level with the bottom line $(0 \%)$. The slider was also moved so the top of the plasma fraction levels with the top line. The adjuster on the left was used to align the middle line with the top of the red cells. The PCV was read from the right-hand side scale.

\subsubsection{Wet Mount}

A drop of blood was dropped on a clean objective glass slide using a plastic pipette. This was then covered with coverslip and immediately examined under the microscope using the x10 and x40 objective lens. 


\subsubsection{Buffy Coat Technique}

After centrifuging, the blood in the capillary was separated into three distinct layers; plasma at the top, the buffy coat at the middle and the red cells at the bottom. The capillary tube was broken at the site red blood cell layer just about $1 \mathrm{~mm}$ below the buffy coat. This was carefully done by pressing and running the sharp edge of an objective glass slide over the capillary tube. The buffy coat with the adjacent plasma was transferred into an objective glass slide, mixed and covered with a coverslip $(18 \times 18 \mathrm{~mm})$ and was examined for motile trypanosomes under microscope using $\mathrm{x} 10$ and $\times 40$ objective lens.

163

164 165 166

\subsubsection{Thin Blood Smear}

A capillary tube was used to place a drop of blood on one end of a clean objective glass slide. Using a clean smooth-edged glass objective slide as spreader, the spreader was drawn back to touch the drop of blood and the blood was allowed to extend along the edge of the spreader. Holding the spreader at about angle $30^{\circ}$, the drop of blood was spread to make a film about 40-50 $\mathrm{mm}$ in length (two thirds of the slide). The film was left for a few minutes to air dry and the specimen number was written on the film for easy identification. The film was placed on a staining rack and fixed in absolute methanol and allowed to dry. After drying, a reverse staining with Field Stain A and B was done and left to dry after which it was viewed under the X100 objective lens.

\subsection{Faecal Sample Analysis}

Collected fecal materials were subjected to centrifugal sedimentation technique and centrifugal fecal flotation technique according to Zajac \& Conboy, 2012.

\subsubsection{Centrifugal Sedimentation Technique}

$10 \mathrm{~g}$ of faeces was put in a dish container and emulsified with $100 \mathrm{~mL}$ of water. The faecal sample was sieved through a tea strainer into a beaker. It was then poured into a $15 \mathrm{~mL}$ centrifuge tube until it was three-quarter full. It was centrifuged for 5 minutes at 1500rpm. After centrifugation, the supernatant was discarded leaving the sediments. Using the Pasteur pipette, a few drops of the sediment were placed on a glass objective slide, covered with a coverslip and viewed under the $\mathrm{x} 10$ and $\mathrm{x} 40$ objective lens. 


\subsubsection{Centrifugation Flotation Technique}

185 Salt/sugar solution was used as flotation solution. It has a specific gravity of 1.28. This was 186 prepared by dissolving $400 \mathrm{~g}$ of Sodium Chloride in $1000 \mathrm{~mL}$ of distilled water to make a saturated 187 solution. $500 \mathrm{~g}$ of sugar was then added to the saturated salt solution and was stirred until the sugar 188 was fully dissolved.

189 Flotation solution was poured into the sediment inside the $15 \mathrm{~mL}$ centrifuge tube until it was almost 190 full and was centrifuged for 5 minutes at 1500rpm. After centrifugation, the tube was removed 191 from the centrifuge and placed in a test tube rack. Additional flotation solution was added until it 192 formed a reverse meniscus at the top of the tube. Coverslip was immediately placed on the tube 193 and allowed to sit for 5 to 10 minutes before removing the coverslip and placed on a glass objective 194 slide for viewing under the microscope using the $\mathrm{x} 10$ and $\mathrm{x} 40$ objective lens.

\section{$195 \quad 2.8$ Data Analysis}

196 The data obtained from the study were analysed descriptively with the use of IBM SPSS 21 197 software package. Descriptive statistics was deployed in determining the prevalence estimates and 198 chi-square analysis were made in comparing the demographic variables with prevalence estimates. 199 The mean Packed Cell Volume (PCV) was ascertained using t-test. Confidence interval was set at $200 P \leq 0.05$. 


\section{RESULTS}

\subsection{The demographic information of cattle in the study area}

207 A total of 256 cattle were examined for haemoparasites and intestinal helminths. According to 208 sample distribution, 217 (84.8\%) blood and stool samples were collected in Lafenwa while 39 (15.2\%) were collected in Aladesanmi abattoirs respectively. In the sex category, 57 (22.3\%) were male while 199 (77.7\%) were female. By age category, 246 (96.1\%) were above 2 years while 10 (3.9\%) were below 2 years. Distribution by breed reflected that 149 (58.2\%), 87 (34.0\%), 17 (6.6\%), $2(0.8 \%)$ and $1(0.4 \%)$ of cattle were white fulani, red bororo, sokoto gudali, N'dama and crossbreed respectively. (Table 1)

3.2 Cumulative Prevalence of Haemoparasites across breed, sex, age and geo-location in the study area

In relation to sex, females had the highest prevalence of Babesia 59 (29.6\%), Trypanosoma 17 (8.5\%), Anaplasma 44 (22.1\%) and Theileria 2 (1.0\%). With regards to breed, Sokoto gudali had the highest prevalence 8 (47.1\%) of Babesia spp., followed by the white fulani 41 (27.5\%), while the red bororo 8 (9.2\%) had the highest prevalence of Trypanosoma spp. followed by white fulani $12(8.1 \%)$. However, the differences in prevalence across breed, sex, age, and location for all the haemoparasites was found to be insignificant $(P>0.05)$. (Table 2)

\subsection{Prevalence of coinfection of haemoparasites}

In relation to breed, white Fulani had the highest prevalence 5 (2.0\%) of coinfection followed by the red Bororo $3(1.2 \%)$, however, using statistical analysis, the difference was found to be insignificant $(P>0.05)$. With respect to sex, females had a higher prevalence $7(2.7 \%)$ of coinfection than male $2(0.8 \%)$ and this difference was found to be significant $(P<0.05)$. With respect to location, cattle at the Lafenwa abattoir had a higher prevalence $9(3.5 \%)$ of coinfection of haemoparasites than the Aladesanmi abattoir which recorded $1(0.4 \%)$ prevalence. The difference in prevalence was found to be significant $(P<0.05)$ (Table 3) 


\subsection{Relationship between haemoparasite infection and the PCV}

234 The mean PCV of infected was 26.46 while for non-infected was 29.28. The mean PCV of those 235 infected was found to be significantly lower than those uninfected $(\mathrm{P}<0.05)$. This means that low PCV could be an indication of the presence of haemoparasites in cattle. (Fig. 1)

\subsection{Prevalence of intestinal helminths in study area}

Helminths detected include Strongyle eggs, Eimeria oocyct, Monieza benedini, Fasciola spp., Neoascaris vitulorum and Cryptosporidium oocyst. Of the 256 samples analysed, Strongyle eggs had the highest prevalence 191 (74.6\%) and Neoascaris vitulorum had the lowest prevalence 2 (0.8\%). Monieza benedini, Eimeria oocyst, Fasciola spp. and Cryptosporidium oocyst had prevalence of 10 (3.9\%), 93 (36.3\%), 26 (10.2\%) and 3 (1.2\%) respectively (Fig. 2)

\subsection{Distribution of Intestinal Helminth infection in Study Area}

Total prevalence of intestinal helminths was 209 (81.64\%). A total of 112 (43.8\%) had single infection of intestinal parasite. $84(32.81 \%)$ had double infection of intestinal parasite while 13 (5.07\%) had multiple infections of intestinal helminths (more than 2 infections of helminth) (Fig. 3)

\subsection{Polyparasitism of Intestinal Helminths across breed, sex, age and location}

Total prevalence of intestinal helminths was found to be 209 (81.64\%). In respect to breed, White Fulani had the highest prevalence of double infection 45 (30.2\%), followed by the red bororo with prevalence of double infection $33(37.9 \%)$ but the difference wasn't significant $(P>0.05)$. With respect to age, cattle above 2 years had higher prevalence of double infection $80(32.9 \%)$ and multiple infection $14(5.8 \%)$ than cattle below 2 years with a prevalence of double infection 3 $(23.1 \%)$ and $0(0 \%)$ multiple infection which were also found to be insignificant $(P>0.05)$ (Table 4) 


\subsection{Prevalence of Fasciola spp. in study area}

261 The prevalence of Fasciola spp. was found to be $26(10.2 \%)$ and all was found at the Lafenwa 262 abattoir. White fulani had the highest prevalence 14 (5.5\%), followed by red bororo $11(4.3 \%)$ and 263 Sokoto gudali $1(0.4)$, this difference was insignificant $(P>0.05)$. In respect to sex, females had 264 higher prevalence $25(9.8 \%)$ than males $1(0.4 \%)$ and the difference was found to be significant $265(P<0.05)$. Age-specific prevalence, cattle above 2years had a higher prevalence $26(10.2 \%)$ than 266 those below 2 years, however, the difference was insignificant $(P>0.05)$ (Table 5)

\subsection{Prevalence of Coinfection of Haemoparasites and Intestinal Helminths in Study Area}

The total prevalence of coinfection of both haemoparasites and intestinal helminth was found to be 109 (42.6\%). White Fulani had the highest prevalence of coinfection 61 (23.8\%) for both haemoparasite and intestinal helminth followed by Red Bororo 41 (16.0\%), although the difference was found to be insignificant $(\mathrm{P}>0.05)$. in respect to age, prevalence was higher in cattle above 2 years $103(40.2 \%)$ than those below 2 years $6(2.3 \%)$ and difference was also found to be insignificant $(\mathrm{P}>0.05)$. However, with respect to sex, females had higher prevalence 92 (35.9\%) for coinfection of both haemoparasites and intestinal helminths than males 17 (6.6\%), this difference in prevalence was found to be significant $(\mathrm{P}<0.05)$ (Table 6)

GIS DISTRIBUTION OF HAEMOPARASITES AND INTESTINAL HELMINTHS IN STUDY AREAS

280 The GIS distribution of haemoparasites and intestinal helminths in the study areas are shown in 281 fig. 4 and fig. 5 respectively. 


\section{DISCUSSIONS}

Findings from this study show that haemoparasites and intestinal helminths are highly prevalent in the study area. The prevalence of 53.9\% of haemoparasites observed in this study is higher than the prevalence observed by Nzeako \& Okorafor (2014) where a prevalence of $6.67 \%$ was reported in their study in Ibadan and also the prevalence of 22\% reported by Okwelum et al. (2021) in their report on epidemiological survey of haemoparasitic infection in trade cattle at slaughter in Lafenwa abattoir but similar to the findings of Akande et al. (2010) where a prevalence of 51\% was reported in their study on haemoparasites in cattle in Abeokuta. This finding is also similar to the findings reported by Talabi et al. (2009), where a prevalence of 50.2\% was reported in the Trans boundary areas of Ogun State, Nigeria and 54\% prevalence in sheep at Abeokuta, Ogun State by Takeet et al. (2009). However, the prevalence of $53.9 \%$ reported in this study is slightly lower than prevalence of 70\% reported by Bakre et al. (2020) in their study in Igboora. The differences in prevalence of haemoparasites values in various locations, according to Velusamy et al. (2014), could be attributed to differences in geographical location and time periods and also differences in distribution of vectors which transmits the parasites (Agbede, 2013).

298

299

300

301

302

303

Breed specific prevalence showed the highest prevalence in the white fulani breed $(31.3 \%)$ followed by the red bororo (18.8\%) and then sokoto gudali (3.5\%), the difference was however not significant $(P>0.05)$. This is almost similar to the finding of Bitrus et al. (2021) in their study of the occurrence of haemoparasites in cattle slaughtered at Jalingo abattoir where the white fulani (13.91\%) had the highest prevalence followed by the red bororo (10.94\%) and sokoto gudali $(10 \%)$. This is most likely due to the fact that the white fulani is the dominant breed in the study area. Sex-specific prevalence, the females had a higher prevalence $(44.9 \%)$ than males $(9.0 \%)$. The difference in prevalence between sexes was found to be significant $(P<0.05)$. This is similar to what was observed by Enwezor et al. (2009), Pam et al. (2013), Nzeakor \& Okorafor (2014), Obed \& Imafidor (2018) and Bitrus et al. (2021). This observable difference could be attributed to accumulation of parasites by the females due to the extended breeding practices for economic reasons such as calving and milk production (Nzeakor \& Okorafor, 2014).

With respect to age, prevalence was higher in cattle above 2years (51.6\%) than those below 2years (2.3\%) even though this difference was found to be statistically insignificant $(P>0.05)$. The difference is probably due to the higher distribution of cattle above 2years. 
313 The high incidence of haemoparasites recorded in this study, according to Adejinmi et al. (2004) 314 could be as a result of favourable environmental condition that helps in the survival and proliferation of the arthropod vectors responsible for the transmission of these parasites. According to oral findings from butchers and cattle owners at the Lafenwa abattoir, it is noteworthy that most of the cattle were brought in from the Northern part of the country. Several studies on infestation of tick on the cattle population in the Northern part shows high prevalence, this may explain the high prevalence of tick-borne diseases observed in this study. Adejoh et al. (2019) reported a prevalence of 56\% tick infestation in their study on survey of ticks and tick-borne parasites in commercial cattle at Lafia, Nasarawa State, Nigeria. Tongjura et al. (2012) and James-Rugu \& Jidayi (2004), in separate studies on tick infestation in the Northern part both reported prevalence of $73.3 \%$ and $81.8 \%$ respectively. This may also be responsible for two tick-borne parasites, Babesia (27.7\%) and Anaplasma (20.7\%) having the highest prevalence in this study.

The mean PCV of infected cattle (26.46) was significantly lower $(P<0.05)$ than non-infected cattle (29.28). This is in line with the observation of Akande et al. (2010), Imalele et al. (2019), Zawua et al. (2015), Sam-wobo et al. (2010) and Bakre et al. (2020). Zawua et al. (2015) opined that the low PCV in infected cattle could be as a result of biochemical activity of the parasites which causes a destruction of the red blood cells, invariably leading to anaemia.

The high prevalence of haemoparasites in this study has further shown that proper vector control methods need to be implemented to ensure prevalence of haemoparasites is significantly reduced. This study also provides the current status on the prevalence of intestinal parasites of cattle slaughtered in Abeokuta, Ogun State and their implications to public health. The overall prevalence of intestinal parasites was 209 (81.6\%) including helminth eggs and Eimeria oocyst. This prevalence is within the range of the finding of Takeet et al. (2014) where the prevalence of 95.12\% was reported in their study on prevalence of gastrointestinal parasites of cattle in Abeokuta and also the finding of Yuguda et al. (2018) where a prevalence of $74.3 \%$ was reported in their study on gastrointestinal helminths of slaughtered cattle in Bauchi Central Abattoir. OkikeOsisiogu et al. (2016) also reported prevalence of $87.4 \%$ in their study on the prevalence of intestinal parasite in cattle slaughtered in Aba. Gastrointestinal nematode was observed to have the highest prevalence (84.8\%), a similar observation to the report of Adedipe et al. (2014) in their study on gastrointestinal helminths in Ibadan where prevalence of $71.7 \%$ was reported. According 
to Jatau et al. (2011), prevailing climatic conditions especially rainfall and temperature favour the development and survival of parasitic nematode eggs to infective stages and this might explain the high prevalence observed as this study was conducted during the early season of rainfall.

High nematode infection greatly affects livestock production by causing reduction in milk, meat, wool, hide products, and strength of animals (Nwosu et al. 2007; Ekong et al. 2012), also leads to decreased growth rate, weight loss in young ruminants and late maturity (Swai et al. 2006). Nematode infection is followed by trematode (10.2\%) and cestode (3.9\%). This is consistent with the observation by Adedipe et al. (2014). A lot of the animals in this study have multiple gastrointestinal parasitic infection suggesting they could be suffering from parasitic gastroenteritis (PGE) complex which is more prevalent during the rainy season (Jatau et al. 2011).

Neoascaris vitulorum (0.8\%) and Fasciola spp. (10.2\%) are two parasites with zoonotic potential observed in this study. The prevalence of Fasciola (10.2\%) is lower than 29.8\% prevalence reported by Karshima et al. (2016) and 27.68\% reported by Magaji et al. (2014) but almost in consonant with the $13.37 \%$ prevalence reported by Liba et al. (2018) in their study on prevalence of fascioliasis in cattle slaughtered at Maiduguri.

Breed-specific prevalence for Fasciola spp., the white fulani had the highest prevalence 14 (5.5\%) followed by the red bororo 11 (4.3\%) and then sokoto gudali 1 (0.4), however, the difference was not significant. With respect to age, cattle above 2years had higher prevalence 26 (10.2) than cattle below 2 years, the difference was also found not to be significant. The huge disparity seems to be as a result of the sample size, however, with respect to sex, females had a higher prevalence 25 (9.8\%) than males $1(0.4 \%)$ and this difference was found to be significant $(P<0.05)$. This finding deviates from the findings of Magaji et al. (2014) and Jegede et al. (2015) but correlates with the reports of Biu et al. (2006), Aliyu et al. (2014) and Karshima et al. (2016) where female cattle had higher prevalence than male. The observable higher prevalence by females may be due to stress associated with hormonal imbalances during pregnancy in female animals which increases their susceptibility to infections coupled with the fact that female cattle are normally kept longer in herds for the purpose of breeding (Karshima et al. 2016). Fasciolosis is a parasitic worm infection of veterinary and medical importance. It is caused by either Fasciola gigantica or Fasciola hepatica. 
372 In this study, Neoscaris vitulorum was also observed with a prevalence of $2(0.8 \%)$. Neoascaris 373 vitulorum (also called Toxocara vitulorum) is the most important parasite responsible for calf 374 mortality and morbidity under three months of age in tropical countries and heavy burden of the 375 adult $T$. vitulorum in young calves could result in high mortality rate and economic losses 376 (Srivastava \& Sharma, 1981).

377 Co-infection of haemoparasites and intestinal helminths was also studied. The overall prevalence 378 of co-infection of at least one haemoparasite and at least one intestinal helminth was found to be 379 380 $109(42.6 \%)$. There was a high prevalence of co-infection of haemoparasite and intestinal helminths in the white fulani 61 (23.8\%), followed by the red bororo $41(16.0 \%)$ and then followed by the Sokoto gudali $7(2.7 \%)$ but the difference was not significant $(P>0.05)$. The prevalence observed is as a result of the disparity in sample size. Sex-specific prevalence, females had higher prevalence $92(35.9 \%)$ of co-infection of haemoparasite and intestinal parasite than males 17 $(6.6 \%)$ and this difference was found to be significant $(P<0.05)$. This was also observed by Pam et al. (2013) in their study on the occurrence of haemoparasite and gastrointestinal parasite of cattle in Jos. The reason for high prevalence in female could be as a result of long-term exposure due to their prolonged stay in herds for production purpose.

According to Pam et al. (2013), the high prevalence of co-infection reported may be as a result of continued contamination of feed and water these animals consume by their faecal matter and even in advance countries where disposal of both animals and human excreta to farm land, and on pasture, may lead to direct infection. Poor farming practices such as poor deworming program, and poor control of ectoparasites may also contribute to the high prevalence of infections.

\subsection{Implications for one health}

The practice of using hands to remove certain tick species especially Amblyomma variegatum by the farmers puts them at risk of tick bites and, consequently to zoonotic pathogens they may transmit (Katswara \& Mukaratirwa, 2021). Amblyomma tick bites are painful and can transmit diseases including African tick bite fever to humans (Anna, 2009). Cattle can also be reservoir host of trypanosome species that can infect man. 
Most intestinal parasites spend a part of their life cycle outside the definitive host when eggs are excreted into the environment. Environmental conditions, biotic (availability of intermediate host and predation of helminth eggs and larva) and abiotic (rainfall, temperature, humidity and soil $\mathrm{pH}$ ) factors play important roles in the survival and transmission of helminths.

There is an interconnectivity between humans and animals and their shared environment. In order to prevent outbreak of zoonotic diseases, the one health approach is important. The One Health strategic goal, according to Sara et al. (2020) is to prevent, detect and control disease that pose a major public health risk and also involve sustainable practices in agriculture and improving the overall health and well-being of humans, animals, and their shared environment. The one health strategy understands the interconnection between people, animals and their environment. It recognizes the fact that a single sector cannot effectively address issues of such a broad interconnectivity and hence proposes a collaborative and interdisciplinary approach with the goal of achieving optimal health outcomes (CDC, 2018). Both from the veterinary and the human public health point of view, fascioliasis is a serious "One-Health" problem (Rinaldi et al. 2012). The one health approach is jointly supported by WHO, FAO, and OIE to tackle zoonotic diseases (Lubroth, 2013; WHO et al. 2019).

Experts in these three sectors need to come up with strategies targeted at investigating some of the knowledge gaps, development of control strategies, vector control, treatment of zoonotic infections and analysis of burdens.

\section{CONCLUSIONS}

In conclusion, this study reveals a high prevalence of tick-borne diseases and intestinal helminths of veterinary and zoonotic importance in cattle slaughtered in Abeokuta. It also reveals complex cases of polyparasitism of intestinal helminths in cattle slaughtered in Abeokuta. The presence of Fasciola spp. at the Lafenwa abattoir which is the major abattoir for beef sourcing in Abeokuta shows that there is a need to ensure strict compliance of meat inspection at abattoirs and also a need for immediate operationalization and implementation of a sustainable Preventive One Health intervention in order to mitigate against outbreak of zoonoses in the study areas. 


\section{DECLARATIONS}

430

431

432

433

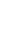$$
18
$$

\section{ETHICS APPROVAL}

Approval and permission for the study was given by the ethics committee of Veterinary Services Unit of the Ogun State Ministry of Agriculture, Abeokuta, Ogun State.

\section{CONSENT FOR PUBLICATION}

Not applicable.

435 AVAILABILITY OF DATA AND MATERIALS

436 The datasets generated during and/or analysed during the current study are available from the 437 corresponding author on reasonable request.

438 COMPETING INTERESTS

439 The authors declare that they have no competing interests.

440 FUNDING

441 The authors declare that no funds, grants, or other support were received for this study.

442 AUTHORS' CONTRIBUTIONS

443 OGD, OS and MR contributed to the study design, data collection and preparation of the 444 manuscript. FA, SA and MA contributed to study design and data analysis. All authors read and 445 approved the final manuscript.

446 ACKNOWLEDGEMENTS

447 The authors are grateful to Mr Olugbogi and Mrs Oduogbolu and other members of the laboratory 448 of Veterinary Microbiology and Parasitology Department, College of Veterinary Medicine, 449 Federal University of Agriculture, Abeokuta for their assistance with the laboratory work. 


\section{REFERENCES}

Adebowale, O., Ekundayo, O., and Awoseyi, A. (2020). Female cattle slaughter and foetal wastage: A case study of the Lafenwa abattoir, Ogun state, Nigeria. Cogent Food \& Agriculture, 6(1). doi: 10.1080/23311932.2020.1809308

Adedipe, O.D., Uwalaka, E.C., Akinseye, V.O., Adediran, O.A., and Cadmus, S.I. (2014). Gastrointestinal Helminths in Slaughtered Cattle in Ibadan, South-Western Nigeria. Journal of Veterinary Medicine, 2014:923561. doi:10.1155/2014/923561

Adejinmi, J.O., Sadiq, N.A., Fashanu, S.O., Lasisi, O.T. and Ekundayo, S. (2004). Study on the blood parasite of sheep in Ibadan, Nigeria. Africa Journal of Biomedical Research, 7:42-43.

462 Adejoh, V., Pam, V., Uzoigwe, N., Naphtali, R.S., Yohanna, J.A., Pam, R and Ombugadu, A. 463 (2019). A survey of ticks and tick-borne parasites in commercial cattle at Lafia, Nasarawa State, 464 Nigeria. Nigerian Journal of Parasitology, 40. doi:10.4314/njpar.v40i2.22.

465 Agbede, R.I.S. (2013). A guide to tropical veterinary Entomology. Mac chin multimedia designers, 466 Zaria, Nigeria. Pp 108-109.

467 Akande, F.A., Takeet, M.I., and Makenju O.A. (2010). Haemoparasites of Cattle in Abeokuta, 468 South. West Nigeria. Short Communication Science World Journal. 5(4):19-21.

469 Aliyu, A.A., Ajogi, I.A., Ajanusi, O.J., Reuben, R.C. (2014). Epidemiological studies of Fasciola 470 gigantic in cattle in Zaria, Nigeria using coprology and serology. Journal of Public Health 471 Epidemiology. 6 (2):85-91.

472 Anna, R.S. (2009). Amblyomma variegatum. Retrieved from 473 http://www.cfsph.iastate.edu/DiseaseInfo/factsheets.php.

474 Bakre, A., Omotosho, O., Adelakun, O., and Alaba, B. (2020). Prevalence of Haemoparasites in 475 Cattle Slaughtered at Central Abattoir in Igboora, Oyo State, Nigeria. International Journal of 476 Livestock Research, 10(10), 74-79. doi: 10.5455/ijlr.20200701081657

477 Bitrus, I., Musa, H.I., Konto, M., Shittu, I., and Balami, P.U. (2021). Occurrence of haemoparasites 478 in cattle slaughtered at Jalingo abattoir, north-eastern Nigeria. Sokoto Journal of Veterinary 479 Sciences, 19(1). 
Biu, A.A. and Adindu, J.U. (2004). The prevalence of bovine hydatidosis in Maiduguri, Nigeria.

\section{Journal of Life and Environmental Science, 6(2): 360-362.}

Biu, A.A., Ahmed, M.I., and Mshelia, S.S. (2006). Economic assessment of losses due to parasitic diseases common at the Maiduguri abattoir, Nigeria African Science. 7(3):143- 145.

Centre for Disease Control (2018). One Health Basics. Retrieved from https://www.cdc.gov/onehealth/basics/index.html

Cheesbrough, M. (1998). District Laboratory Practice in Tropical Countries. Part 1. Cambridge University Press, London.

Ekong, P. S., Juryit, R., Dika, N. M., Nguku, P., \& Musenero, M. (2012). Prevalence and risk factors for zoonotic helminth infection among humans and animals - Jos, Nigeria, 2005-2009. The Pan African medical journal, 12, 6.

Enwezor F.N.C., Umoh, J.U., Esievo, K.A.N., Halid I, Zaria L.T., and Anere, J.I (2009). Survey of bovine trypanosomosis in the Kachia Grazing Reserve, Kaduna State, Nigeria. Veterinary Parasitology, $159: 121-125$.

Faye, D., Leak, S., Nouala, S., Fall, A., Losson, B., and Geerts, S. (2003). Effects of Gastrointestinal helminth infections and plan of nutrition on the health and productivity of (West African Dwarf Sahelian) goat crosses in The Gambia. Small Ruminant Research, 50:153-161. Doi: 10.1016/S0921-4488(03)00108-1.

Imalele, E., Offiong, E., and Usang, A. (2019). Haemoparasitic infection and haematological indices of cattle slaughtered for sale in Calabar, Nigeria. International Journal of Veterinary Sciences and Animal Husbandry, 4(4): 07-11

James-Rugu, N.N., and Jidayi, S. (2004). A survey of some ectoparasites on some livestock from some areas of Borno and Yobe States. Nigerian Veterinary Journal, 25(2): 48-55.

Jatau, I.D., Abdulganiyu, A., Lawal, A.I., Okubanjo, O.O., and Yusuf, K.H. (2011). Gastrointestinal and haemoparasitism of sheep and goats at slaughter in Kano, northern-Nigeria. Sokoto Journal of Veterinary Sciences, 9(1):7-11. 
Jegede, O.C., Adejoh, A.A., Obeta, S.S., and Olayemi, O.D. (2015). Gastrointestinal parasites of sheep and goats in Gwagwalada Area Council, Federal Capital Territory, Abuja, Nigeria; with a special reference to sex, breed and age. Alexandria Journal of Veterinary Sciences, 46: 170-176.

Kamani, J., Sannusi, A., Egwu, O., Dogo, G., \& Tanko, T.J., Kemza, S., Tafarki, A.E. and Gbise, D.S. (2010). Prevalence and Significance of Haemoparasitic Infections of Cattle in North-Central, Nigeria. Veterinary World. 3:445. doi:10.5455/vetworld.2010.445-448.

Karshima, N.S., Shalangwa, I., and Bobbo, A.A. (2016). Prevalence, Risk Factors and Economic Losses Associated with Fasciolosis in Slaughtered Cattle in Bauchi, North-Eastern Nigeria. Alexandria Journal of Veterinary Sciences. 50. 87. doi:10.5455/ajvs.225556.

Katswara, T., and Mukaratirwa, S. (2021). Knowledge, attitudes and practices on African tick bite fever of rural livestock communities living in a livestock-wildlife interface area in the Eastern Cape Province of South Africa. BMC Infect Dis 21, 497. doi:10.1186/s12879-021-06174-9

518 Lawal-Adebowale, O. (2012). Dynamics of Ruminant Livestock Management in the Context of 519 the Nigerian Agricultural System.

520 Liba, J., Francis, M., and Atsanda, N. (2018). Prevalence of fascioliasis in cattle slaughtered at 521 Maiduguri Municipal Abattoir, Borno State, Nigeria. Nigerian Journal of Parasitology. 39:242. 522 Doi:10.4314/njpar.v39i2.22.

523 Love, S.C.J., and Hutchinson, G.W. (2003). Pathology and Diagnosis of Internal Parasites in 524 Ruminants, Journal of Veterinary Parasitology; volume 350, pp 309-338.

525 Lubroth, J. (2013) FAO and the one health approach. Curr Top Microbiol Immunol. 366:65-72. 526 doi: 10.1007/978-3-662-45791-7_262 40.

527 Magaji, A., Ibrahim, K., Salihu, M.D., Saulawa, M.A., Mohammed, A., and Ibrahim, A. (2014). 528 Prevalence of Fascioliasis in Cattle Slaughtered in Sokoto Metropolitan Abattoir, Sokoto, Nigeria. 529 Advances in Epidemiology. doi: 10.1155/2014/247258.

530 Musa, H.I, Jajere, S.M, Adamu, N.B, Atsanda N.N, Lawal, J.R, Adamu, S.G, and Lawal, E.K., 531 (2014). Prevalence of Tick Infestation in Different Breeds of Cattle in Maiduguri, Northeastern 532 Nigeria. Bangladesh Journal of Veterinary Medicine.12(2):161-166 
Nwosu, C.O., Madu, P.P., and Richards, W.S. (2007). Prevalence and seasonal changes in the population of gastrointestinal nematodes of small ruminants in the semi-arid zone of north-eastern Nigeria. Veterinary parasitology, 144(1-2), 118-124.

Nzeako, S., and Okorafor, U. (2014). Prevalence of Haemoparasites of Cattle from Three Abattoirs in Ibadan Metropolis, Oyo State, Nigeria. International Journal of Scientific Research in Environmental Sciences. 2. 244-249. doi:10.12983/ijsres-2014-p0244-0249.

Obed, J., and Imafidor, H. (2018). Haemoparasites of Bovine (Sokoto gudali) Species Slaughtered in Port Harcourt Metropololis, Rivers State, Nigeria. Asian Journal of Biology. 5. 1-8. doi:10.9734/AJOB/2018/39625.

Ochai J.A and Kolhatkar, A.A. (2007). Medical Laboratory Science Theory and Practice. Department of Microbiology College of Medicine Sultan, Qaboos University, Muskat. Pp315-512 Okike-Osisiogu, F.U., Arinze, A.G., and Ekaiko, M.U. (2016). Prevalence of intestinal parasite in cattle slaughtered in Aba.

546 Okwelum, N., Iposi, S.O., Sowande, O.S., Smith, O., and Takeet, M. (2021). Epidemiological 547 survey of haemoparasitic infection in trade cattle at slaughter in Lafenwa abattoir, Ogun State, 548 Nigeria. Nigerian Journal of Animal Production, 41, 187-195.

549 Otto, H (2005). Merck Veterinary Manual, by Merck and Co. Ninth Edition. Merck Sharp and 550 Dohme Corp, a subsidiary of Merck and Co., Inc. Whitehouse Station, NJ, USA.

551 Otto, H., Radostits, C., Gray, C., Blood, D.C., and Hinchcliff, K.W. (2000). Veterinary medicine, 552 a text book of the diseases of cattle, sheep, pigs, goats and horses, ninth edition.

553 Pam, V., Ogbu, K., Igeh, P. and Bot, G (2013). The Occurrence of Gastrointestinal and Haemo 554 parasites of cattle in Jos of Plateau State, Nigeria. Journal of Animal Science Advances. 3. 97. 555 doi:10.5455/jasa.20130226010552.

556 Rinaldi, L., Gonzalez, S., Guerrero, J., Aguilera, L., Musella, V., Genchi, C., and Cringoli, G. 557 (2012). A One-Health integrated approach to control fascioliasis in the Cajamarca valley of Peru. 558 Geospatial Health, 6. S67-73. Doi:10.4081/gh.2012.124. 
Sam-Wobo, S., Igenezoa, A., Idowu, O., Otesile, E., Ekpo, U., and Kehinde, O. (2010). Bovine

560 trypanosomosis and its impact on cattle in derived savanna areas of Ogun State, Nigeria. Journal 561 of Public Health and Epidemiology, 1:43-47.

562 Sam-Wobo, S., Uyigue, J., Surakat, O., Adekunle, O., and Mogaji, H. (2016). Babesiosis and Other 563 Heamoparasitic Disease in a Cattle Slaughtering Abattoir in Abeokuta, Nigeria. International 564 Journal of Tropical Disease \& Health, 18:1-5. doi:10.9734/IJTDH/2016/27280.

565 Sara, N.G., Osburn B.I., and Jay-Russell, M.T. (2020). One Health for Food Safety, Food Security, 566 and Sustainable Food Production. Frontiers in Sustainable Food Systems, 4 (1). 567 doi:10.3389/fsufs.2020.00001

568 Schalm, O.W., Jain, N.C., Carrol, E.J. (1975). Veterinary Haematology, 3rd Edition. Lea and 569 Febiger, Philadephia, 15-81

570 Stuen, S. (2020). Haemoparasites - Challenging and Wasting Infections in Small Ruminants: A 571 Review. Animals. doi: 10.2179.10.3390/ani10112179.

572 Swai, E.S, Mtui, P.F, Mbise, A.N, Kaaya, E., Sanka, P., and Loomu, P.M. (2006). Prevalence of 573 gastro intestinal parasite infections in Maasai cattle in Ngorongoro District, Tanzania," Livestock 574 Research for Rural Development, vol. 18, no. 8.

575 Takeet, M.I., Akande, F.A., and Abakpa S.A. (2009). Haemoprotozoan parasites of sheep in 576 Abeokuta, Nigeria. Nigerian Journal of Parasitology, 30(20): 142-146

577 Takeet, M.I., Badru, O., Olubgbogi, E., and Abakpa, S.A. (2014). Prevalence of gastrointestinal 578 parasites of cattle in Abeokuta, Ogun State, Nigeria. Nigerian Journal of Animal Science, 18, 458579465.

580 Talabi, A.O., Oyekunle, M.A., Oyewusi, I.K., Otesile, E.B., Adeleke, G.A. and Olusanya, T.P. 581 (2009). Parasites of Cattle in the Trans-boundary Areas of Ogun State, Nigeria. Synopses, 582 FAO/IAEA International Symposium on Sustainable Improvement of Animal Production and 583 Health. Vienna, Austria. Pp331.www.naweb.iaea.org/nafa/aph/Book of Synopses.pdf Published 584 by FAO/IAEA 
585 Tongjura, J., Amuga, D.C., G. A., Ombugadu, R. J., Azamu, Y., and Mafuiya, H.B. (2012). 586 Ectoparasites infesting livestock in three local government areas (LGAs) of Nasarawa State, 587 Nigeria. Science World Journal, 7(1): 15-17.

588 Velusamy, R., Rani, N., Ponnudurai, G., Harikrishnan, T.J., Anna, T., Arunachalam, K., 589 Senthilvel, K., and Anbarasi, P. (2014). Influence of season, age and breed on prevalence of 590 haemoprotozoan diseases in cattle of Tamil Nadu, India. Veterinary World, 7:574-578. 591 Doi:10.14202/vetworld.2014.574-578

592 World Health Organization, Food and Agriculture Organization of the United Nations, World 593 Organisation for Animal Health (2019). Taking a Multisectoral, One Health Approach: A 594 Tripartite Guide to Addressing Zoonotic Diseases in Countries. FAO - OIE - WHO (2019). 151 p. 595 Available online at: https://apps. who.int/iris/handle/10665/325620

596 Yadav, A., Khajuria, J.K and Raina, A.K (2006). Seasonal prevalence of gastrointestinal parasites 597 in sheep and goats of Jammu. Indian Veterinary Journal. 20:65-68.

598 Yuguda, A., Samaila, A., and Panda, S. (2018). Gastrointestinal helminths of slaughtered cattle in 599 Bauchi Central Abattoir, Bauchi State, Nigeria. GSC Biological and Pharmaceutical Sciences. 4: 600 058-065. doi:10.30574/gscbps.2018.4.2.0036.

601 Zahid, I.A., Latif, M. and Baloch, K.B. (2005). Incidence of endoparasites in exotic cattle calves. 602 Pakistan Veterinary Journal, 25(1): 67-70.

603 Zajac, A., and Conboy, G.A. (2012). Veterinary clinical parasitology. Chichester, West Sussex, 604 UK: Wiley-Blackwell. 6-7.

605 Zawua, T.P., Amali, O., Amuta, E.U., and Sar, T.T. (2015). Haemoparasites of cattle slaughtered 606 for sale within Gboko Metropolis of Benue State, Nigeria. Nigerian Journal of Parasitology. 607 36(1):72-76. 


\section{LIST OF FIGURES}

Fig 1: Relationship between haemoparasite infection and PCV

Fig 2: Prevalence of intestinal helminths in study area

Fig 3: Distribution of coinfection of intestinal helminth infection in study area

Fig 4: Distribution of haemoparasites using GIS

Fig 5: Distribution of intestinal helminths using GIS 


\section{MEAN PCV}

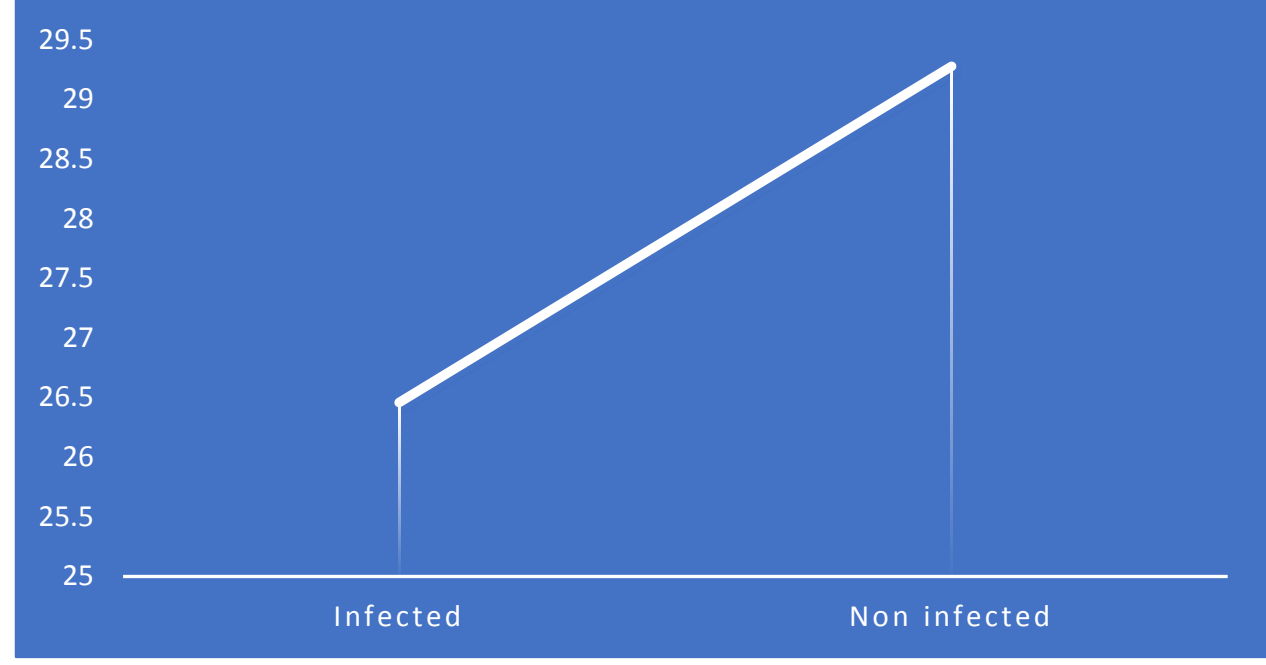

$p=0.002$

Fig 1: Relationship between haemoparasite infection and PCV 


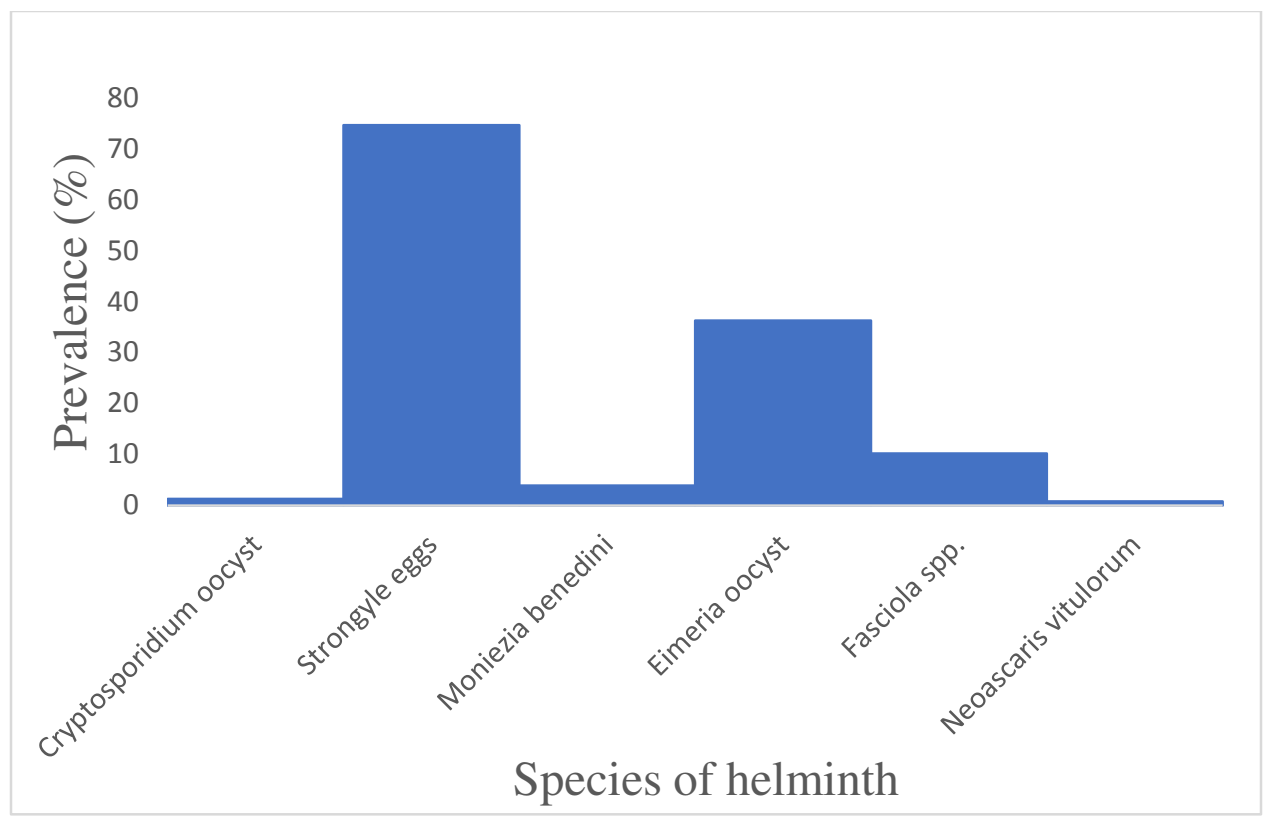

Fig 2: Prevalence of intestinal helminths in study area 


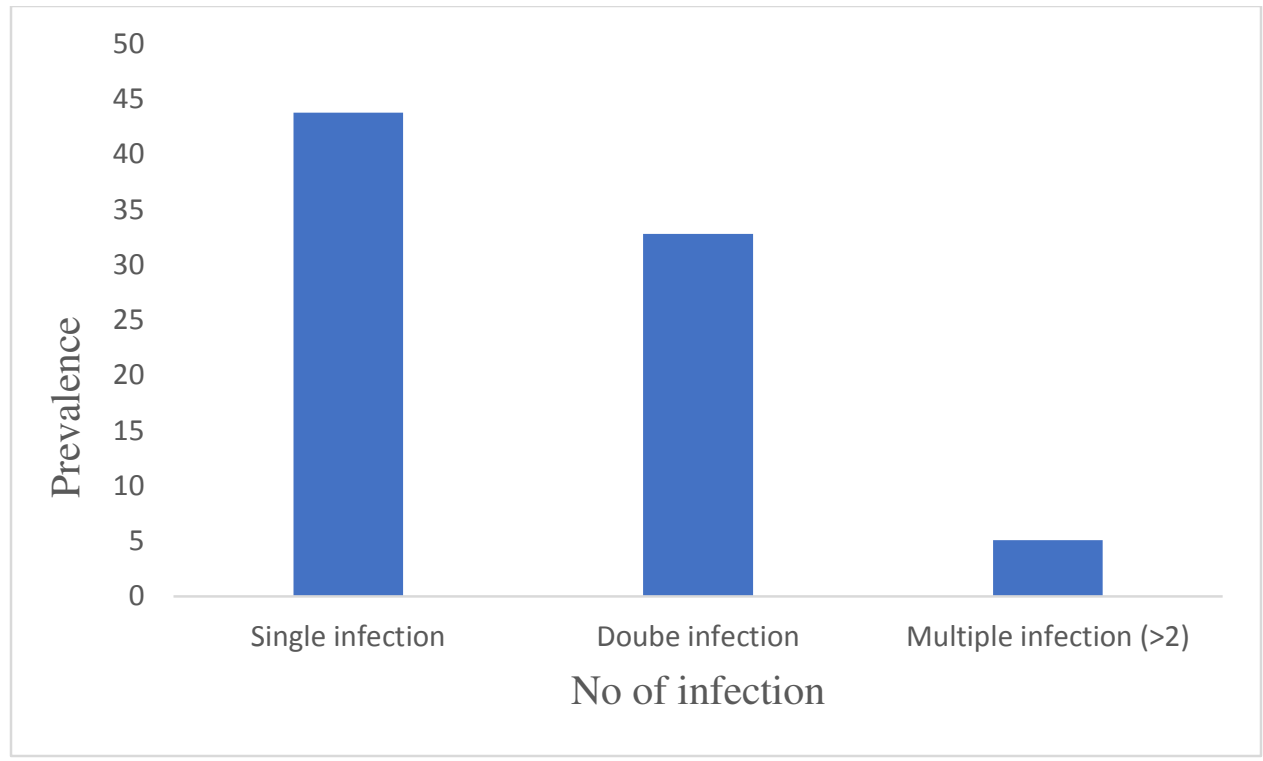

Fig 3: Distribution of coinfection of intestinal helminth infection in study area 


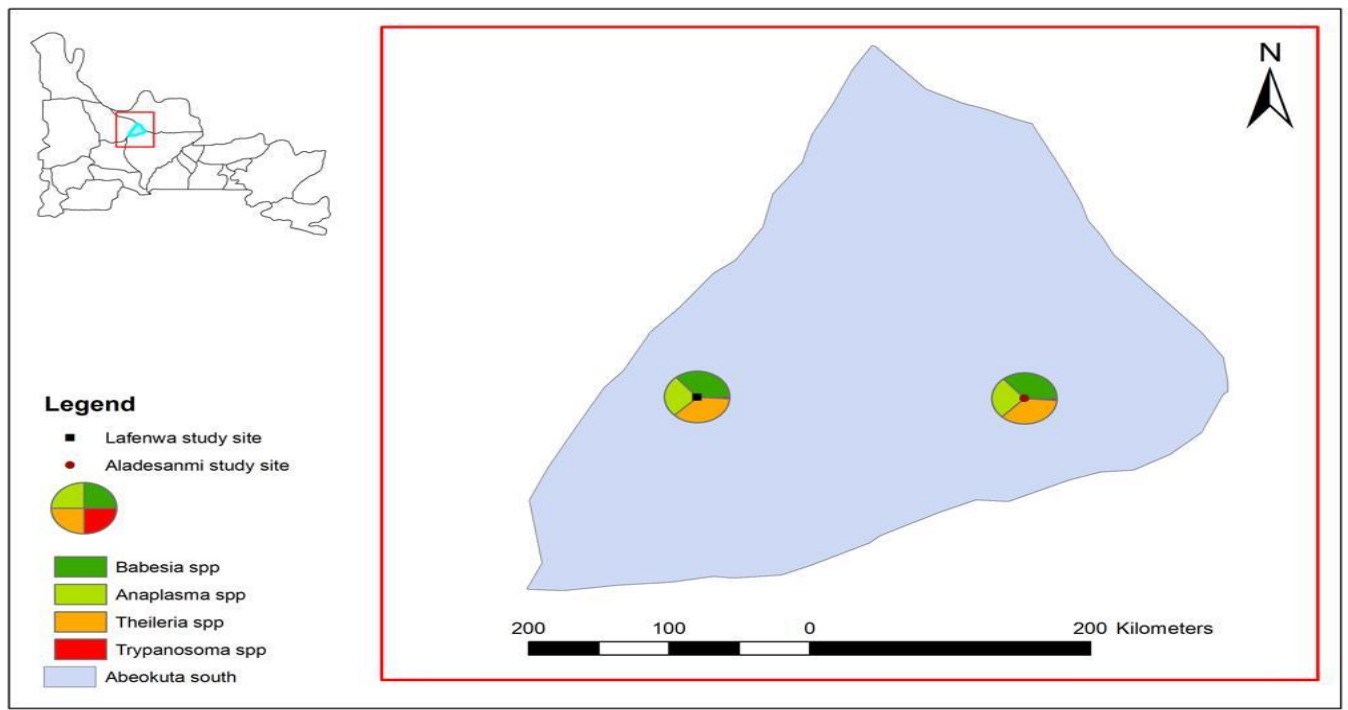

Fig 4: Distribution of haemoparasites using GIS 


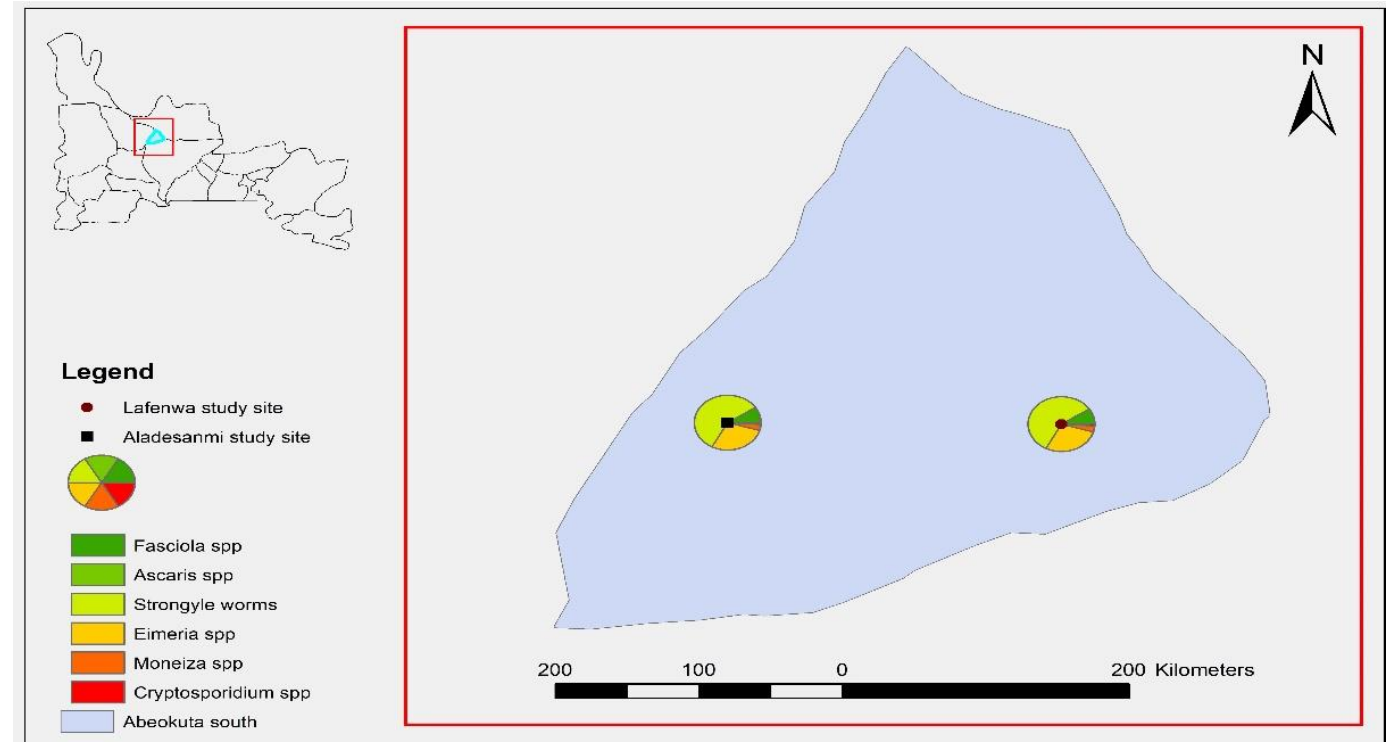

Fig 5: Distribution of intestinal helminths using GIS 


\section{LIST OF TABLES}

Table 1: Demographic information of cattle in the study area

Table 2: Cumulative prevalence of haemoparasites across breed, sex, age and location in the study area

Table 3: Prevalence of coinfection of haemoparasites

Table 4: Polyparasitism of Intestinal Helminths across breed, sex, age and location

Table 5: Prevalence of Fasciola spp. in study areas

Table 6: Prevalence of Co-infection of Haemoparasites and Intestinal Helminths in Study Area 
Table 1: Demographic information of cattle in the study area

\begin{tabular}{|c|c|}
\hline & No examined $(\%)$ \\
\hline \multicolumn{2}{|l|}{ Location } \\
\hline Lafenwa & $217(84.8)$ \\
\hline Aladesanmi & $39(15.2)$ \\
\hline Total $(\%)$ & $256(100)$ \\
\hline \multicolumn{2}{|l|}{ Sex } \\
\hline Male & $57(22.3)$ \\
\hline Female & $199(77.7)$ \\
\hline Total $(\%)$ & $256(100)$ \\
\hline \multicolumn{2}{|l|}{ Breed } \\
\hline White Fulani & $149(58.2)$ \\
\hline Red Bororo & $87(34.0)$ \\
\hline Sokoto Gudali & $17(6.6)$ \\
\hline N'dama & $2(0.8)$ \\
\hline Crossbreed & $1(0.4)$ \\
\hline Total $(\%)$ & $256(100)$ \\
\hline \multicolumn{2}{|l|}{ Age } \\
\hline$>2$ & $246(96.1)$ \\
\hline$<2$ & $10(3.9)$ \\
\hline Total $(\%)$ & $256(100)$ \\
\hline
\end{tabular}


Table 2: Cumulative prevalence of haemoparasites across breed, sex, age and location in the study area

\begin{tabular}{|c|c|c|c|c|c|}
\hline & No examined & $\begin{array}{l}\text { Babesia spp. } \\
(\%)\end{array}$ & $\begin{array}{l}\text { Theileria spp. } \\
(\%)\end{array}$ & $\begin{array}{l}\text { Anaplasma } \\
\text { spp. }(\%)\end{array}$ & $\begin{array}{l}\text { Trypanosoma } \\
\text { spp. }(\%)\end{array}$ \\
\hline \multicolumn{6}{|l|}{ SEX } \\
\hline Male & 57 & $12(21.1)$ & $0(0)$ & $9(15.8)$ & $4(7.0)$ \\
\hline Female & 199 & $59(29.6)$ & $2(1.0)$ & $44(22.1)$ & $17(8.5)$ \\
\hline Total $(\%)$ & 256 & $71(27.7)$ & $2(0.8)$ & $53(20.7)$ & $21(8.2)$ \\
\hline$P$ value & & $P=0.24$ & $P=0.44$ & $P=0.29$ & $P=0.7$ \\
\hline \multicolumn{6}{|l|}{ AGE } \\
\hline$>2$ & 246 & $69(28.0)$ & $2(0.8)$ & $51(20.7)$ & $19(7.7)$ \\
\hline$<2$ & 10 & $2(20.0)$ & $0(0)$ & $2(20)$ & $2(20)$ \\
\hline Total $(\%)$ & 256 & $71(27.7)$ & $2(0.8)$ & $53(20.7)$ & $21(8,2)$ \\
\hline$P$ value & & $P=0.57$ & $P=0.77$ & $P=0.95$ & $P=0.16$ \\
\hline \multicolumn{6}{|l|}{ BREED } \\
\hline White fulani & 149 & $41(27.5)$ & $2(1.34)$ & $30(20.1)$ & $12(8.1)$ \\
\hline Red bororo & 87 & $21(24.1)$ & $0(0)$ & $22(25.3)$ & $8(9.2)$ \\
\hline Sokoto & 17 & $8(47.1)$ & $0(0)$ & $1(5.9)$ & $1(5.9)$ \\
\hline \multicolumn{6}{|l|}{ Gudali } \\
\hline N'dama & 2 & $0(0)$ & $0(0)$ & $0(0)$ & $0(0)$ \\
\hline Cross Breed & 1 & $1(100)$ & $0(0)$ & $0(0)$ & $(0)$ \\
\hline Total $(\%)$ & 256 & $71(27.7)$ & $2(0.8)$ & $53(20.7)$ & $21(8.2)$ \\
\hline$P$ value & & $P=0.13$ & $P=0.83$ & $P=0.38$ & $P=0.97$ \\
\hline \multicolumn{6}{|l|}{ LOCATION } \\
\hline Aladesanmi & 39 & 7 (17.9) & $0(0)$ & $6(15.4)$ & $4(10.3)$ \\
\hline Lafenwa & 217 & $64(29.5)$ & $2(0.9)$ & $47(21.7)$ & $17(7.8)$ \\
\hline Total $(\%)$ & 256 & $71(27.7)$ & $2(0.8)$ & $53(20.7)$ & $21(8.2)$ \\
\hline$P$ value & & $P=0.17$ & $P=0.54$ & $P=0.37$ & $P=0.61$ \\
\hline
\end{tabular}


Table 3: Prevalence of coinfection of haemoparasites

\begin{tabular}{|c|c|c|c|c|}
\hline & No examined & $\begin{array}{l}\text { No infected } \\
(\%)\end{array}$ & $\begin{array}{l}\text { Single } \\
\text { infection }(\%)\end{array}$ & $\begin{array}{l}\text { Co-infection } \\
(\%)\end{array}$ \\
\hline \multicolumn{5}{|l|}{ SEX } \\
\hline Male & 57 & $23(9.0)$ & $21(8.2)$ & $2(0.8)$ \\
\hline Female & 199 & $115(44.9)$ & $108(42.2)$ & $7(2.7)$ \\
\hline Total $(\%)$ & 256 & $138(53.9)$ & $129(50.4)$ & $9(3.5)$ \\
\hline$P$ value & & & & $P=0.02$ \\
\hline \multicolumn{5}{|l|}{ AGE } \\
\hline$>2$ & 246 & $132(51.6)$ & $123(48.05)$ & $9(3.5)$ \\
\hline$<2$ & 10 & $6(2.3)$ & $6(2.3)$ & $0(0)$ \\
\hline Total $(\%)$ & 256 & $138(53.9)$ & $129(50.35)$ & $9(3.5)$ \\
\hline$P$ value & & & & $p=0.12$ \\
\hline \multicolumn{5}{|l|}{ BREED } \\
\hline White fulani & 149 & $80(31.3)$ & $75(29.3)$ & $5(2.0)$ \\
\hline Red bororo & 87 & $48((18.8)$ & 45 (17.6) & $3(1.2)$ \\
\hline Sokoto Gudali & 17 & $9(3.5)$ & $8(3.1)$ & $1(0.4)$ \\
\hline N'dama & 2 & $0(0)$ & $0(0)$ & $0(0)$ \\
\hline Cross Breed & 1 & $1(0.39)$ & $1(0.39)$ & $0(0)$ \\
\hline Total $(\%)$ & 256 & $138(53.9)$ & $129(50.39)$ & $9(3.6)$ \\
\hline$P$ value & & & & $p=0.29$ \\
\hline \multicolumn{5}{|l|}{ LOCATION } \\
\hline Aladesanmi & 39 & $16(6.2)$ & $15(5.9)$ & $1(0.4)$ \\
\hline Lafenwa & 217 & $122(47.7)$ & $113(44.1)$ & $9(3.5)$ \\
\hline Total $(\%)$ & 256 & $138(53.9)$ & $128(50.0)$ & $10(3.9)$ \\
\hline Pvalue & & & & $p=0.08$ \\
\hline
\end{tabular}


Table 4: Polyparasitism of Intestinal Helminths across breed, sex, age and location

\begin{tabular}{llllll}
\hline & No examined & $\begin{array}{l}\text { Single } \\
\text { Infection }(\%)\end{array}$ & $\begin{array}{l}\text { Double } \\
\text { infection }(\%)\end{array}$ & $\begin{array}{l}\text { Multiple } \\
\text { infection }>2 \\
(\%)\end{array}$ & $P$ value \\
& & & & \\
SEX & 57 & $25(43.9)$ & $20(35.1)$ & $0(0)$ & \\
Male & 199 & $87(43.7)$ & $63(31.7)$ & $14(7.0)$ & \\
Female & 256 & $112(43.8)$ & $83(32.4)$ & $14(5.5)$ & $p=0.55$
\end{tabular}

AGE

\begin{tabular}{lllll}
$>2$ & 246 & $105(42.7)$ & $80(32.5)$ & $14(5.7)$ \\
$<2$ & 10 & $7(70.0)$ & $3(30.0)$ & $0(0)$ \\
\hline
\end{tabular}

$\begin{array}{lllll}\text { Total }(\%) & 256 & 112(43.8) & 83(32.4) & 14(5.5)\end{array}$$$
p=0.12
$$

BREED

$\begin{array}{lllll}\text { White fulani } & 149 & 65(43.6) & 45(30.2) & 9(6.0) \\ \text { Red bororo } & 87 & 37(42.5) & 33(37.9) & 4(4.6) \\ \text { Sokoto Gudali } & 17 & 9(52.9) & 4(23.5) & 1(5.9) \\ \text { N'dama } & 2 & 0(0) & 0(0) & 0(0) \\ \text { Cross Breed } & 1 & 1(50.0) & 1(50.0) & 0(0)\end{array}$

\begin{tabular}{lllll}
\hline Total $(\%)$ & 256 & $112(43.8)$ & $83(32.4)$ & $14(5.5)$
\end{tabular}

$$
p=0.29
$$

LOCATION

\begin{tabular}{llllll} 
Aladesanmi & 39 & $19(48.7)$ & $13933.3)$ & $0(0)$ & \\
Lafenwa & 217 & $93(42.9)$ & $70(32.3)$ & $14(6.5)$ & \\
\hline Total $(\%)$ & 256 & $112(43.8)$ & $83(32.4)$ & $14(5.5)$ & \\
& & & & $p=0.94$ \\
\hline
\end{tabular}


Table 5: Prevalence of Fasciola spp. in study areas

\begin{tabular}{|c|c|c|c|}
\hline & No examined & No infected (\%) & $P$ value \\
\hline \multicolumn{4}{|l|}{ BREED } \\
\hline White fulani & 149 & $14(5.5)$ & \\
\hline Red bororo & 87 & $11(4.3)$ & \\
\hline Sokoto gudali & 17 & $1(0.4)$ & \\
\hline N'dama & 2 & $0(0)$ & \\
\hline Crossbreed & 1 & $0(0)$ & \\
\hline \multirow[t]{2}{*}{ Total $(\%)$} & 256 & $26(10.2)$ & \\
\hline & & & $p=0.73$ \\
\hline \multicolumn{4}{|l|}{ SEX } \\
\hline Male & 57 & $1(0.4)$ & \\
\hline Female & 199 & $25(9.8)$ & \\
\hline \multirow[t]{2}{*}{ Total $(\%)$} & 256 & $26(10.2)$ & \\
\hline & & & $p=0.017$ \\
\hline \multicolumn{4}{|l|}{ AGE } \\
\hline$>2$ & 246 & $26(10.2)$ & \\
\hline$<2$ & 10 & $0(0)$ & \\
\hline \multirow[t]{2}{*}{ Total $(\%)$} & 256 & $26(10.2)$ & \\
\hline & & & $p=0.278$ \\
\hline
\end{tabular}


Table 6 Prevalence of Co-infection of Haemoparasites and Intestinal Helminths in Study Area

\begin{tabular}{|c|c|c|c|c|}
\hline & No examined & $\begin{array}{l}\text { Coinfection of } \\
\text { Haemoparasites }+ \\
\text { Intestinal } \\
\text { helminths }\end{array}$ & $\begin{array}{l}\text { Prevalence } \\
(\%)\end{array}$ & Pvalue \\
\hline SEX & & & & \\
\hline Male & 57 & 17 & 6.6 & \\
\hline Female & 199 & 92 & 35.9 & \\
\hline Total & 256 & 109 & 42.6 & $p=0.02$ \\
\hline AGE & & & & \\
\hline$>2$ & 246 & 103 & 40.2 & \\
\hline$<2$ & 10 & 6 & 2.3 & \\
\hline Total & 256 & 109 & 42.6 & $p=0.25$ \\
\hline BREED & & & & \\
\hline White fulani & 149 & 61 & 23.8 & \\
\hline Red bororo & 87 & 41 & 16.01 & \\
\hline Sokoto Gudali & 17 & 7 & 2.7 & \\
\hline N'dama & 2 & 0 & 0 & \\
\hline Cross Breed & 1 & 0 & 0 & \\
\hline Total & 256 & 109 & 42.6 & $p=0.47$ \\
\hline LOCATION & & & & \\
\hline Aladesanmi & 39 & 12 & 4.7 & \\
\hline Lafenwa & 217 & 97 & 37.9 & \\
\hline Total & 256 & 109 & 42.6 & $p=0.10$ \\
\hline
\end{tabular}

